Journal of Telenursing (JOTING)

Volume 1, Nomor 2, Desember 2019

e-ISSN: 2684-8988

p-ISSN: 2684-8996

DOI: https://doi.org/10.31539/joting.v1i2.511

\title{
PENGARUH DANCE MOVEMENT THERAPY TERHADAP PERUBAHAN TEKANAN DARAH PADA LANSIA HIPERTENSI
}

\author{
Supriadin $^{1}$, Agung Waluyo ${ }^{2}$, Rohman Azzam ${ }^{3}$ \\ Sekolah Tinggi Ilmu Kesehatan Yahya Bima ${ }^{1}$ \\ Universitas Indonesia ${ }^{2}$ \\ Universitas Muhammadiyah Jakarta ${ }^{3}$ \\ supriadinmyusuf@gmail.com ${ }^{1}$
}

\begin{abstract}
ABSTRAK
Penelitian ini bertujuan untuk mengetahui pengaruh dance movement therapy terhadap perubahan tekanan darah pada lansia hipertensi. Desain penelitian ini menggunakan quasi eksperiment pre-post with control group. Hasil penelitian menunjukan perbedaan yang signifikan dalam perubahan tekanan darah sistol dan diastol setelah di berikan perlakuan dance movement therapy $(\mathrm{t}=2,781, \mathrm{p}=0,013), \mathrm{t}=2,465, \mathrm{p}=0,025)$, serta terjadi perubahan tekanan darah sistol dan diastol setalah intervensi pada kelompok kontrol $(\mathrm{t}=1,458, \mathrm{p}=$ $0,163), \mathrm{t}=0,606, \mathrm{p}=0,552)$. Simpulan, dance movement therapy dapat menurunkan tekanan darah sistol secara bermakna pada pasien hipertensi.
\end{abstract}

Kata Kunci : Dance Movement Therapy, Hipertensi Primer, Tekanan Darah

\section{ABSTRACT}

This study aims to determine the effect of dance movement therapy on changes in blood pressure in hypertensive elderly. The research design used a quasi-experimental pre-post control group. The results showed a significant difference in changes in systolic and diastolic blood pressure after being given dance movement therapy $(t=2.781, p=0.013), t=2.465, p$ $=0.025)$, as well as changes in systolic and diastolic blood pressure after the intervention at control group $(t=1.458, p=0.163), t=0.606, p=0.552)$. In conclusion, dance movement therapy can significantly reduce systolic blood pressure in hypertensive patients.

\section{Keywords: Dance Movement Therapy, Primary Hypertension, Blood Pressure}

\section{PENDAHULUAN}

Lansia merupakan tahap akhir siklus hidup manusia, bagian dari proses kehidupan yang tak dapat dihindarkan dan akan dialami oleh setiap individu. Dalam tahap ini individu mengalami banyak perubahan baik secara fisik maupun mental, khususnya kemunduran dalam berbagai fungsi dan kemampuan yang pernah dimilikinya. Perubahan penampilan fisik sebagian dari proses penuan normal, seperti rambut yang mulai memutih, kerut-kerut ketuaan di wajah, berkurangnya ketajaman panca indera, serta kemunduran daya tahan tubuh, merupakan acaman bagi integritas orang usia lanjut. Belum lagi mereka harus berhadapan dengan kehilangan - kehilangan peran diri, kedudukan sosial, serta perpisahan dengan orangorang yang dicintai. Semua hal tersebut menuntut kemampuan beradaptasi yang cukup besar untuk dapat menyikapi secara bijak (Setyoadi \& Kushariyadi, 2011). 
Berdasarkan definisi secara umum, seseorang di katakan lanjut usia (lansia) apabila usianya 65 tahun ke atas, lansia bukan suatu penyakit, namun merupakan tahap lanjut dari suatu proses kehidupan yang di tandai dengan penurunan kemampuan tubuh untuk beradaptasi dengan stres lingkungan serta di tandai dengan kegagalan seseorang untuk mempertahankan keseimbangan terhadap kondisi stres fisiologis, kegagalan ini berkaiatan dengan penurunan daya kemampuan untuk hidup serta peningkatan kepekaan secara individual. Penyakit degeneratif yang kerap dialami oleh lansia diantaranya osteoarthritis, osteoporosis, hipertensi, diabetes mellitus, dimensia, penyakit jantung koroner, dan kanker (Makhfudli, 2013).

Hipertensi merupakan gangguan pada pembuluh darah yang mengakibatkan suplai oksigen dan nutrisi yang dibawah oleh darah terhambat sampai ke jaringan tubuh yang membutuhkan. Hipertensi merupakan penyakit tidak menular yang menjadi masalah kesehatan di seluruh dunia karena prevalensinya tinggi (Lidya, 2009). Hipertensi juga bisa muncul sebagai efek samping dari obat gagal ginjal dan perawatan penyakit jantung bawaan, kondisi tersebut dinyatakan dengan hipertensi sekunder (Padila, 2012). Hipertensi disebut sebagai the silent killer, karena tidak menampakkan gejala yang khas. WHO memperkirakan sekitar 30\% penduduk dunia tidak menyadari adanya hipertensi dan pada tahun 2025 prevalensi hipertensi akan terus meningkat (Susilo \& Wulandari, 2011). Hipertensi merupakan penyebab kematian nomor 3 setelah stroke dan tuberkulosis, yakni mencapai $6,7 \%$ dari populasi kematian.

Organisasi kesehatan dunia WHO menyatakan dari seluruh populasi di dunia, angka kejadian hipertensi diperkirakan mampu menyebabkan 7,5 juta kematian dan sekitar 12,8\% dari seluruh angka kematian. Data WHO pada tahun 2013 menunjukkan prevalensi penderita hipertansi di usia 25 tahun dan lebih mencapai 40\% (Cahyani, 2014). Kawasan Asia Tenggara termasuk Indonesia, dilaporkan bahwa 49,7\% penyebab kematian adalah akibat penyakit tidak menular, salah satu di antaranya adalah hipertensi (Irawan, 2017; Sartika et al., 2018).

Prevalensi hipertensi di Indonesia ini merupakan salah satu masalah kesehatan dangan angka kejadian yang tinggi yaitu sebesar 25,8\%. Terdapat 5 wilayah di Indonesia dengan angka kejadian hipertensi tertinggi, yaitu di Bangka Belitung $(30,9)$, diikuti daerah Kalimantan Selatan $(30,8 \%)$, Kalimantan Timur $(29,6)$, Jawa Barat $(29,4 \%)$, dan Gorontalo $(29,4 \%)$. Sedangkan prevalensi hipertensi di Provinsi Bengkulu sudah mencapai sebesar 21,6\% (Riskesdas, 2013). Dengan tingginya angka kejadian hipertensi yang ada di Indonesia namun upaya untuk mengendalikan hipertensi tersebut masih kurang, perlu adanya berbagai macam upaya yang bisa dilakukan untuk mengendalikan angka kejadian hipertensi yang tinggi tersebut sehingga dapat menekan angka hipertensi (Andri et al., 2018).

Penyebab terjadinya hipertensi adalah terdiri dari berbagai faktor, diantaranya faktor faktor resiko yang menyebabkan hipertensi adalah stress, kegemukan, merokok. Sedangkan hipertensi sekunder merupakan tekanan darah tinggi yang disebabkan karena penyakit kelenjar adrenal, penyakit ginjal, toxemia gravidarum, penekanan intra kranial yang disebabkan karena tumor otak dan pengaruh obat tertentu misalnya obat kontrasepsi (Sarif, 2012).

Terapi nonfarmakologis selalu menjadi pilihan yang dilakukan penderita hipertensi karena biaya yang dikeluarkan untuk terapi farmakologis relatif mahal. Langkah awal pengobatan hipertensi nonfarmakologis adalah dengan menjalani pola hidup sehat, salah satunya dengan terapi komplementer yang menggunakan bahan-bahan alami yang ada disekitar kita dan mudah untuk di lakukan seperti relaksasi otot progresif, meditasi, aromaterapi, terapi herbal, terapi nutrisi. Terapi relaksasi memberikan individu mengontrol diri ketika terjadi rasa tidak nyaman atau nyeri (Susilo \& Wulandari, 2011). Memperhatikan terapi nonfarmakologi bisa di lakukan pada pasien hipertensi salah satunya adalah tari dan gerak yang dimana tujuan yaitu untuk memberikan rasa rileks. 
Terapi tari dan gerak merupakan bentuk refleks gerak seseorang berasal dari pikiran dan perasaan. Melalui pengetahuan dan dukungan klien, perawat membantu perkembangan dan pengintegrasian pola gerak adaptif baru bersama dengan pengalaman emosional yang diiringi beberapa perubahan. Terapi tari dan gerak diberikan bagi individu dan kelompok terapi dalam konteks kesehatan, pendidikan, sosial, dan dalam latihan pribadi, terapi tari dan gerak tidak hanya mengajarkan kemampuan menari atau latihan gerak. Terapi tari dan gerak mempunyai dua asumsi pokok yaitu bagaimana klien dapat mengontrol diri dan mengekspresikan perasaan serta merupakan pendekatan holistis yang penting bagi tubuh, proses berpikir, dan bekerja mengacu pada integrasi diri. Individu selalu mengungkapkan diri dalam gerak dan tari. Perilaku individu yang dikenal dengan baik ini dapat dilihat kerangka teori digunakan untuk mendeskripsikan proses dan hasil akhir terapi tari dan gerak (Setyoadi \& Kushariyadi, 2011). Memperhatikan tari dan gerak ialah satu penatalaksanaan non farmakologi yang dapat dilakukan pada lansia dengan hipertensi menggunakan teknik tari dan gerak yaitu dance movement therapy.

\section{METODE PENELITIAN \\ Desain Penelitian}

Desain penelitian yang di gunakan quasi eksperiment pre-post with control group adapun intervensi yang di lakukan DMT. Pada awal penelitian dilakukan penilaian tekanan darah pada kelompok perlakuan dan kelompok kontrol, kemudian perlakuan intervensi DMT diberikan, maka penilaian akan di lakukan pada kelompok intervensi dan kelompok kontrol. Penelitian ini membandingkan kelompok yang diberikan perlakuan DMT dengan kelompok yang tidak diberikan perlakuan. Penelitian ini di lakukan di Puskesmas Kecematan Monta Kabupaten Bima.

\section{Participant}

Pada penelitian ini, populasi yang digunakan adalah 48 lansia mengalami hipertensi primer yang berada di Desa Tangga wilayah kerja Puskesmas Kecematan Monta Kabupaten Bima.

\section{Intervention group}

Pada kelompok perlakuan yang di berikan intervensi DMT dilakukan sealama 2 kali seminggu selama 4 minggu, peneliti mengukur tekanan darah responden sebelum di lakukan intervensi pada hari pertama, data ini di gunakan sebagai pretest. Kemudian di lakukan pengukuran tekanan darah lagi stelah 4 minggu di lakuan intervensi, data ini di gunakan sebagai posttest.

\section{Control Group}

Pada kelompok kontrol tidak diberikan terapi DMT peneliti mengukur tekanan darah responden. Data ini digunakan sebagai data pretest. Setelah minggu, selama 2 kali seminggu dilakukan pengukuran kembali tekanan darah, data ini digunakan sebagai data post test.

\section{Ethical Consideration}

Penelitian ini dilakukan setelah mendapat persetujuan dari dewan peninjauan etika atau telah lolos kaji etik di Universitas Muhammadiyah Jakarta. Peneliti telah menjelaskan tentang penelitian ini kepada para calon responden termasuk tujuan, metode, manfaat dan risikonya. Peneliti menjamin kerahasiaan para peserta dan memberikan hak kepada responden bahwa mereka dapat menarik diri dari penelitian kapanpun tanpa implikasi untuk perlakuan selanjutnya. 


\section{Analisis Statistik}

Statistik deskriptif dilakukan untuk mengetahui gambaran karakteristik sampel dan pengukuruan darah. Paired t test dilakukan untuk melihat perbedaan tekanan darah sebelum dan setelah pemberian DMT pada kelompok perlakuan dan kontrol serta membuktikan hipotesispenelitian. Data yang telah terkumpul diolah dengan menggunakan aplikasi SPSS versi 19. Sebelum uji bivariat, sudah dilakukan uji normalitas data denganmenggunakan uji Shapiro-Wilk. Uji normalitas dilakukan pada tekanan darah masing-masing kelompok perlakuan dari kedua waktu pengukuran. Sehingga didapatkan $p$ value $>0,05$ yang berarti data berdistribusi normal. Uji homogenitas dengan Levene's test pun telah dilakukan terlebih dahulu hingga didapatkan $p$ value $>0,05$.

\section{HASIL PENELITIAN}

\section{Analisi Univariat}

Karakteristik Responden

Tabel. 1

Distribusi Responden

Berdasarkan Usia

\begin{tabular}{llllcccc}
\hline Variabel & Kelompok & N & Mean & SD & Min-Mak & \multicolumn{2}{c}{$95 \%$ CI } \\
& & & & & & Min & Mak \\
\hline Umur & Perlakuan & 18 & 71,11 & 5.155 & $63-79$ & 68,38 & 73,33 \\
& Kontrol & 18 & 70,00 & 5,111 & $63-79$ & 67,83 & 72,22 \\
& Total & 36 & 70,56 & 5,090 & $63-79$ & 68,89 & 72,17 \\
\hline
\end{tabular}

Berdasarkan tabel 1 hasil analisis data karakteristik umur pada kelompok perlakuan DMT didapatkan bahwa rata-rata umur responden adalah 71,11 tahun, dengan standar deviasi 5.155. Umur terendah adalah 68 tahun dan umur tertinggi adalah 79 tahun. Sedangkan ratarata umur responden pada kelompok kontrol adalah 70,00 tahun, dengan standar deviasi 5,111. Umur terendah adalah 63 tahun dan umur tertinggi adalah 79 tahun.

Tabel. 2

Distribusi Responden Berdasarkan Jenis Kelamin, Riwayat Hipertensi Keluarga, Riwayat Merokok dan Olahraga

\begin{tabular}{lccccccc}
\hline \multirow{2}{*}{ Variabel } & Kategori & \multicolumn{2}{c}{ Kelompok Perlakuan } & \multicolumn{2}{c}{ Kelompok Kontrol } & \multicolumn{2}{c}{ Total } \\
& & $\mathrm{N}$ & $\%$ & $\mathrm{~N}$ & $\%$ & $\mathrm{~N}$ & $\%$ \\
\hline Jenis Kelamin & Laki-Laki & 11 & 30,5 & 10 & 27,8 & 21 & 58,3 \\
& Perempuan & 7 & 19,4 & 8 & 22,2 & 15 & 41,7 \\
\hline Riwayat HT & Tidak Ada & 6 & 16,7 & 8 & 22,2 & 14 & 38,9 \\
Keluarga & Ada & 12 & 13,3 & 10 & 27,8 & 22 & 61,1 \\
\hline Riwayat merokok & Tidak ada & 8 & 22,2 & 6 & 16,7 & 14 & 38,9 \\
& Ada & 10 & 27,8 & 12 & 33,3 & 22 & 61,1 \\
\hline Olahraga & Tidak ada & 12 & 33,3 & 11 & 30,5 & 23 & 63,9 \\
& Ada & 6 & 16,7 & 7 & 19,4 & 13 & 36,1 \\
\hline
\end{tabular}

Berdasarkan tabel 2 hasil analisis didapatkan sebagian besar $(58,3 \%)$ responden penelitian adalah laki - laki pada total kelompok perlakuan dan kelompok kontrol. Sedangkan responden yang memiliki jenis kelamin perempuan sebanyak 41,7\%) total kelompok perlakuan dan kelompok kontrol. Sebagian besar $(61,1 \%)$ responden memiliki riwayat keluarga yang menderita hipertensi pada total kelompok perlakuan dan kelompok kontrol. Sedangkan responden yang tidak memiliki riwayat keluarga menderita hipertensi sebanyak $(38,9 \%)$ pada total kelompok perlakuan dan kelompok kontrol. Sebagian besar $(61,1 \%)$ responden yang tidak memiliki riwayat merokok pada total kelompok perlakuan dan kelompok kontrol. Sedangkan yang tidak memiliki riwayat merokok sebanyak $(38,9 \%)$ pada 
total kelompok perlakuan dan kelompok control. Sebagian besar $(63,9 \%)$ responden yang tidak memiliki kebiasaan berolahraga pada total kelompok perlakuan dan kelompok kontrol. Sedangkan yang memiliki kebiasaan merokok sebanyak $(36,1 \%)$ pada total kelompok perlakuan dan kelompok kontrol.

Tabel. 3

Tekanan Darah Sistol Responden Sebelum dan Setelah Diberikan Perlakuan

\begin{tabular}{|c|c|c|c|c|c|c|c|c|}
\hline \multirow[t]{2}{*}{ Variabel } & \multirow[t]{2}{*}{ Kelompok } & \multirow[t]{2}{*}{$\mathrm{N}$} & \multirow[t]{2}{*}{ Mean } & \multirow[t]{2}{*}{ SD } & \multirow{2}{*}{$\begin{array}{l}\text { Min- } \\
\text { Mak }\end{array}$} & \multicolumn{2}{|c|}{$95 \% \mathrm{CI}$} & \multirow[t]{2}{*}{$p$ value } \\
\hline & & & & & & Min & Mak & \\
\hline Tekanan & Perlakuan & 18 & 191,67 & 22,19 & $160-240$ & 181,67 & 202,22 & \\
\hline $\begin{array}{l}\text { Darah Sistol } \\
\text { Sebelum } \\
\text { Perlakuan }\end{array}$ & Kontrol & 18 & 182,22 & 22,63 & $150-230$ & 172,22 & 192,78 & 0,703 \\
\hline Total & & 36 & 186,94 & 22,41 & & & & \\
\hline Tekana & Perlakuan & 18 & 179,44 & 32,44 & $100-240$ & 163,90 & 193,89 & \\
\hline $\begin{array}{l}\text { Darah Sistol } \\
\text { Sesudah } \\
\text { Perlakuan }\end{array}$ & Kontrol & 18 & 181,11 & 21,93 & $150-230$ & 171,13 & 191,11 & 0,172 \\
\hline Total & & 36 & 180,28 & 27,18 & & & & \\
\hline
\end{tabular}

Berdasarkan tabel 3 rata-rata tekanan darah sistol pada kelompok perlakuan sebelum dilakuan intervensi adalah $186,94 \mathrm{mmHg}$ dengan standar deviasi 22,41 , rata rata tekanan darah sistol pada kelompok perlakuan yang di berikan intervensi DMT lebih tinggi $(191,67$ mmHg $\pm 22,19)$ dibandingkan dengan kelompok kontrol yang tidak diberikan intervensi $(182,22 \mathrm{mmHg} \pm 22,63)$. Kemudian jika dibandingkan dengan susudah di berikan perlakuan terjadi penurunan rata-rata tekanan darah sistol sesudah intervensi, baik pada kelompok perlakuan maupun kelompok kontrol, yaitu masing-masing $(179,44 \mathrm{mmHg} \pm 32,44)$ dan $(181,11 \mathrm{mmHg} \pm 21,93)$. Uji kesetaraan pada kedua menunjukan bahwa secara statistik tekanan darah kelompok perlakuan dan kontrol setara.

Tabel. 4

Tekanan Darah Diastol Responden Sebelum dan Setelah Diberikan Perlakuan

\begin{tabular}{|c|c|c|c|c|c|c|c|c|}
\hline \multirow[t]{2}{*}{ Variabel } & \multirow[t]{2}{*}{ Kelompok } & \multirow[t]{2}{*}{$\mathrm{N}$} & \multirow[t]{2}{*}{ Mean } & \multirow[t]{2}{*}{ SD } & \multirow{2}{*}{$\begin{array}{l}\text { Min- } \\
\text { Mak }\end{array}$} & \multicolumn{2}{|c|}{$95 \% \mathrm{CI}$} & \multirow[t]{2}{*}{$p$ value } \\
\hline & & & & & & Min & Mak & \\
\hline Tekanan Darah & Perlakuan & 18 & 106,11 & 12,43 & $90-130$ & 100,0 & 111,67 & 0,422 \\
\hline Diastol Sebelum & & & & & & 0 & & \\
\hline Perlakuan & Kontrol & 18 & 101,67 & 16,18 & $80-130$ & 94,44 & 108,90 & \\
\hline Total & & 36 & 103,89 & 14,30 & & & & \\
\hline Tekanan Darah & Perlakuan & 18 & 97,22 & 10,74 & $80-120$ & 92,78 & 102,22 & 0,443 \\
\hline Diastol Sesudah & Kontrol & 18 & 99,44 & 13,92 & $80-130$ & 93,33 & 105,54 & \\
\hline Perlakuan & & & & & & & & \\
\hline Total & & 36 & 98,33 & & & & & \\
\hline
\end{tabular}

Berdasarkan tabel 4 rata-rata tekanan darah diastol pada kelompok perlakuan sebelum dilakuan intervensi adalah $103,89 \mathrm{mmHg}$ dengan standar deviasi 14,30 , rata rata tekanan darah diastol pada kelompok perlakuan yang di berikan intervensi DMT lebih tinggi $(106,11$ $\mathrm{mmHg} \pm 12,43)$ di bandingkan dengan kelompok kontrol yang tidak diberikan intervensi $(101,67 \mathrm{mmHg} \pm 61,18)$. Kemudian jika di bandingkan dengan sesudah diberikan perlakuan terjadi penurunan rata-rata tekanan darah diastol sesudah intervensi, baik pada kelompok perlakuan maupun kelompok kontrol, yaitu masing-masing $(97,22 \mathrm{mmHg} \pm 10,74)$ dan $(99,4$ 
mmHg $\pm 13,92$ ). Uji kesetaraan pada kedua menunjukan bahwa secara statistik tekanan darah kelompok perlakuan dan kontrol setara.

\section{Analisi Bivariat}

Tabel. 5

Pengaruh DMT terhadap Tekanan Darah Sistol dan Diastol Sebelum dan Sesudah pada Kelompok Perlakuan

\begin{tabular}{ccccccc}
\hline \multicolumn{2}{c}{ Variabel } & Kelompok & Mean & SD & Selisih Mean & P \\
\hline \multirow{3}{*}{ Perlakuan } & Sistol & Sebelum & 191,67 & 22,82 & 12,23 & $0,013^{*}$ \\
& & Sesudah & 179,44 & 32,44 & & \\
& Diastol & Sebelum & 106,11 & 12,43 & 8.89 & $0,025^{*}$ \\
\hline
\end{tabular}

Berdasarkan tabel 5 nilai rata-rata tekanan darah sistol pada kelompok perlakuan sebelum intervensi sebesar 191,67 dengan standar deviasi 22,82 dan rata rata tekanan darah sistol pada kelompok perlakuan sesudah intervensi sebesar 179,44 dengan standar deviasi 32,44 . Selisih mean untuk sistol yaitu 12,23. Hasil uji paired t test tekanan darah sistol pada kelompok perlakuan diperoleh nilai $\mathrm{p}$ value $=0,013$ yang artinya adalah ada perbedaan yang signifikan pada tekanan darah sistol sebelum dan sesudah diberikan perlakuan DMT. Dilihat dari selisih nilai sistol sebelum dan sesudah di lakukan perlakuan, artinya tekanan darah cenderung menurun setelah diberikan perlakuan.

Sedangkan nilai rata-rata tekanan darah diastol pada kelompok perlakuan sebelum intervensi sebesar 106,11 dengan standar deviasi 12,43 dan rata rata tekanan darah diastol pada kelompok perlakuan sesudah intervensi sebesar 97,22 dengan standar deviasi 10,74. Selisih mean untuk diastol yaitu 8,89. Hasil uji paired t test tekanan darah diastol pada kelompok perlakuan diperoleh nilai $\mathrm{p}$ value $=0,025$ yang artinya ada perbedaan yang signifikan pada tekanan darah diastolik sebelum dan sesudah diberikan perlakuan DMT. Dilihat dari selisih nilai diastol sebelum dan sedudah di lakukan perlakuan, artinya tekanan darah cenderung menurun setelah diberikan perlakuan.

Tabel. 6

Pengaruh DMT terhadap Tekanan Darah Sistol dan Diastol

Sebelum dan Sesudah pada Kelompok Kontrol

\begin{tabular}{ccccccc}
\hline Variabel & & Kelompok & Mean & SD & Selisih Mean & p value \\
\hline \multirow{3}{*}{ Kontrol } & Sistol & Sebelum & 182,22 & 22,63 & 1,11 & 0,163 \\
& & Sesudah & 181,11 & 21,93 & & \\
\cline { 2 - 6 } & Diastol & Sebelum & 101,67 & 16,17 & 2,23 & 0,552 \\
& & Sesudah & 99,44 & 13,92 & & \\
\hline
\end{tabular}

Berdasarkan tabel 6 nilai rata-rata tekanan darah sistol pada kelompok kontrol sebelum intervensi sebesar 182,22 dengan standar deviasi 22,63 dan rata rata tekanan darah sistol pada kelompok kontrol sesudah intervensi sebesar 181,11 dengan standar deviasi 21,93. Selisih mean untuk diastol yaitu 1,11 . Hasil uji paired t test tekanan darah sistol pada kelompok kontroldiperoleh nilai $\mathrm{p}$ value $=0,163$ yang artinya adalah tidak ada perbedaan yang signifikan pada tekanan darah sistol sebelum dan sesudah pada kelompok kontrol .

Sedangkan nilai rata-rata tekanan darah diastol pada kelompok kontrol sebelum intervensi sebesar 101,67 dengan standar deviasi 16,179 dan rata rata tekanan darah diastol pada kelompok kontrol sesudah intervensi sebesar 99,44 dengan standar deviasi 13,921. Selisih mean untuk diastol yaitu 2,23. Hasil uji paired t test tekanan darah diastol pada 
kelompok kontrol diperoleh nilai $\mathrm{p}$ value $=0,552$ yang artinya adalah tidak ada perbedaan yang signifikan pada tekanan darah diastol sebelum dan sesudah pada kelompok kontrol.

\section{PEMBAHASAN}

\section{Karakterisitk Responden}

Hasil penelitian ini menunjukkan bahwa rerata usia pada kelompok perlakuan lebih tinggi bandingkan dengan kelompok kontrol, namun pada hasil analisis menunjukkan tidak ada perbedaan rerata yang bermakna antara usia kelompok intervensi dan kelompok kontrol, sehingga dapat disimpulkan bahwa usia responden antar kelompok perlakuan dan kelompok kontrol setara atau homogen.

Hasil ini sesuai dengan penelitian Sugiharto et al., (2003) yang menjelaskan bahwa umur merupakan faktor risiko terjadinya hipertensi dan menunjukkan hubungan yang signifikan. Berdasarkan analisa multivariat didapatkan responden yang berumur 55-65 tahun berpeluang 4.76 kali menderita hipertensi dibandingkan dengan yang berumur 36-45 tahun (1,23 kali) dan 46-55 tahun (2,22 kali).

Hasil penelitian ini menunjukkan bahwa mayoritas laki-laki lebih tinggi di bandingkan perempuan, baik itu pada kelompok perlakuan maupun pada kelompok kontrol. Hasil penelitian ini berbeda dengan hasil penelitian yang di lakukan oleh beberapa penelitian yaitu Rosano et al., (2006) menyatakan bahwa hipertensi lebih banyak ditemukan pada perempuan dibandingkan dengan laki-laki. Penelitian Yuliarti (2007) pada lansia di Bogor, menemukan bahwa perempuan lebih beresiko untuk menderita hipertensi dibanding laki-laki $(\mathrm{OR}=1.04)$. Potter \& Perry (2005) mengatakan bahwa wanita setelah menopause cenderung memiliki tekanan darah yang lebih tinggi daripada pria. Peningkatan kejadian disebabkan karena penurunan hormon estrogen pasca menopause yang menyebabkan terjadinya perubahan seperti peningkatan berat badan, sensitifitas terhadap garam dan terganggunya fungsi pembuluh darah. Namun hal ini tidak sesuai dengan teori yang mengatakan bahwa pada keseluruhan insiden, hipertensi lebih banyak terjadi pada laki-laki dibandingkan dengan perempuan sampai kira-kira umur 55 tahun. Risiko pada laki-laki dan perempuan hampir sama antara usia 55 sampai 74 tahun, kemudian setelah usia 74 tahun, wanita beresiko lebih besar (Black \& Hawk, 2009). Hasil penelitian Cheriyan et al., (2010) menyebutkan bahwa laki-laki lebih banyak menderita hipertensi.

Responden pada penelitian ini memiliki riwayat keluarga yang menderita hipertensi. Hal ini sesuai dengan kajian literatur oleh Black \& Hawks (2009) yang menjelaskan bahwa pada seseorang dengan riwayat hipertensi keluarga, beberapa gen mungkin berinteraksi dengan yang lainnya dan juga lingkungan yang dapat menyebabkan tekanan darah naik dari waktu ke waktu (hipertensi dianggap poligenik dan multifaktorial). Kecenderungan genetis yang membuat keluarga tertentu rentan terhadap hipertensi mungkin berhubungan dengan peningkatan kadar natrium intraselular dan penurunan rasio kalsium-natrium. Klien dengan orang tua yang memiliki hipertensi berada pada risiko hipertensi yang lebih tinggi.

Responden pada penelitian ini sebagian besar memiliki riwayat merokok. Hubungan merokok dengan hipertensi memang belum jelas. Menurut literatur, nikotin dan karbondioksida yang terkandung dalam rokok akan merusak lapisan endotel pembuluh darah arteri, elastisitas pembuluh darah berkurang sehingga menyebabkan tekanan darah meningkat (Riskesdas, 2007). Mekanisme ini menjelaskan mengapa responden yang merokok setiap hari memiliki risiko untuk menderita hipertensi. Hasil penelitian ini sesuai dengan hasil penelitian Rahyani (2007) didapatkan $80 \%$ dari penderita hipertensi mempunyai riwayat merokok. Hasil ini juga didukung oleh penelitian Pradono (2010) yang menyatakan responden dengan perilaku tidak sehat (merokok, minuman keras dan kurang olahraga) mempunyai risiko 1,53 kali menderita hipertensi dibandingkan dengan responden yang berperilaku sehat. 
Responden dalam penelitian ini tidak memiliki kebiasaan olahraga. Menurut Sacher et al., (2004) olahraga meruapakan kegiatan yang melibatkan tubuh seperti berjalan, berlari, senam bersepeda. Menurut Sugiharto (2007) yang menyatakan bahwa tidak teratur melakukan olahraga akan meningkatkan resiko terkena hipertensi sebesar 2,33 kali di bandingkan dengan yang teratur olahraga.

\section{Pengaruh DMT terhadap Tekanan Darah Sistol, Diastol Sebelum dan Sesudah pada Kelompok Perlakuan dan Kontrol}

Hasil penelitian ini menunjukkan bahwa pasien hipertensi yang diberikan DMT memperlihatkan perubahan tekanan darah sistolik dan diastolik yang bermakna antara sebelum dan setelah melakukan DMT pada kelompok perlakuan yang di berikan perlakuan. Sedangkan pada pasien hipertensi yang tidak dilakukan latihan tidak menunjukkan perubahan ke arah penurunan yang signifikan terhadap tekanan darah sistolik maupun diastolik.

Dalam penelitian ini menggunakan kelompok kontrol sehingga didapatkan hasil bahwa terjadinya penurunan yang signifikan dari tekanan darah sistol maupun diastol setelah dilakukannya DMT. Hasil penelitian lain oleh Aweto et al., (2012) yang dilakukan selama 4 minggu sebanyak 8 kali dengan mengambil sampel secara acak pada 2 kelompok: kelompok A (kelompok DMT) dan kelompok B (kelompok kontrol). 38 subjek menyelesaikan penelitian dengan kelompok DMT yang memiliki total 23 subjek (10 laki-laki dan 13 perempuan), dan kelopok kontrol 15 subjek (6 laki-laki dan 9 perempuan) didapatkan hasil adanya perbedaan yang signifikan secara statistik pada tekanan darah sistol, diastol, denyut nadi, denyut jantung dan volume oksigen maksimal. Sedangkan pada kelompok B tidak ada perbedaan yang signifikan yang diamati pada variabel hasil subjek pada kelompok B. Sehingga dapat disimpulkan bahwa DMT efektif dalam meningkatkan parameter kardiovaskuler dan diperkirakan konsumsi oksigen maksimal pada pasien hipertensi.

DMT yaitu kegiatan yang merangsang intelektual yang bertujuan untuk mempertahakan kesehatan otak dengan melakukan gerak badan. Dengan melakukan DMT secara teratur akan berdampak positif terhadap kelancaran organ tubuh seperti jantung yang akan lancar memompa darah sehingga mampu menghasilkan oksigen yang optimal menuju otak, paruparu terlatih untuk mengeluarkan gas sisa metabolisme tubuh. Mekanisme yang menjelaskan hubungan antara aktifitas fisik dengan fungsi kognitif yaitu aktifitas fisik menjaga dan mengatur vaskularisasi ke otak dengan menurunkan tekanan darah, meningkatkan kadar lipoprotein, meningkatkan produksi endhotelial nitric oxide dan menjamin perfusi jaringan otak yang kuat, efek langsung terhadap otak yaitu memelihara sruktur saraf dan meningkatkan perluasan serabut saraf, sinap-sinap dan kapilaris (Weuve et al., 2004 ).

\section{Pengaruh DMT terhadap Perbuahan Tekanan Darah Sebelum dan Sesudah pada Kelompok Perlakuan dan Kontrol}

Hasil penelitian ini menunjukkan bahwa ada perbedaan yang signifikan antara kelompok perlakuan dan kontrol karena lebih besar nilai pada kelompok perlakuan yang di berikan DMT dengan kelompok kontrol yang tidak di berikan perlakuan.

Berdasarkan penelitian yang dilakukan oleh Agarwal et al., (2014) yang menjelaskan dari 50 sampel yang digunakan dibagi menjadi 2 kelompok. Kelompok 1 (kelompok eksperimen) menjalankan pelatihan selama 1 bulan dengan terapi gerakan 3 kali seminggu untuk durasi 45 menit dan kelompok 2 (kelompok kontrol). Sehingga hasil yang di peroleh adalah kelompok 1 menunjukkan perubahan yang signifikan secara statistik $(\mathrm{P}=0)$ pada tingkat stres setelah terapi selama 1 bulan sedangkan pada kelompok 2 tidak menunjukkan perubahan. Maka dapat disimpulkan bahwa terapi gerakan membantu untuk mengurangi tingkat stres pada siswa fisioterapi. Hasil penelitian cross sectional yang dilakukan pada sampel sejumlah 91 orang di puskesmas Nusa Indah Kota Bengkulu pada tahun 2012, 
menunjukan bahwa stres secara signifikan berpengaruh terhadap tingkat hipertensi nilai $\mathrm{p}$ =0,03 (Mahmudi, 2012). Penelitian yang dilakukan Amriana (2012) menunjukkan stres memiliki hubungan dengan hipertensi (Nilai $\mathrm{p}=0,021$ ). Demikian juga halnya dengan penelitian yang dilakukan di Daerah Pedesaan Oyo Barat Daya Nigeria terhadap 166 pria dan 201 wanita dewasa tahun 2014, menunjukkan bahwa stres secara signifikan berpengaruh kepada hipertensi nilai $\mathrm{p}=0,01$ (Abdulsalam et al., 2014).

Hal ini sejalan dengan penelitian yang dilakukan oleh peneliti bahwa DMT akan mempengaruhi neurotrasmiter endorphin (hormon bahagia) sehingga individu merasa bahagia dan terjadinya peningkatan produksi serotinin, serotonin membantu menyampaikan pesanpesan dari satu tempat ke tempat lain dalam otak. Karena sel-selnya terdistribusi secara luas, serotonin dipercaya mempengaruhi berbagai fungsi psikologis dan fungsi tubuh lainnya. Pengaruh serotonin ini berkaitan dengan mood, hasrat seksual, fungsi seksual, nafsu makan, tidur, ingatan dan pembelajaran, pengaturan temperatur, dan sifat-sifat sosial. Oleh karena produksi serotinin meningkat sehingga otak berada dalam irama yang baik ketika berolahraga. Ketika tubuh menjadi rileks aliran darah menjadi stabil dan kerja jantung menjadi stabil.

Frekuensi kontak sosial dan tingginya integrasi sosial dan keterikatan sosial dapat mengurangi atau memperberat efek stress pada hipotalamus dan sistim saraf pusat. Hubungan sosial ini dapat mengurangi kerusakan otak dan efek penuaan. Makin banyaknya jumlah jaringan sosial mempunyai hubungan dengan fungsi kognitif/mengurangi rata-rata penurunan kognitif 39\% (Wueve et al, 2004 ).

\section{SIMPULAN}

Rata-rata usia responden adalah 63-79 Tahun, sebagian besar berjenis kelamin perempuan, lebih dari separuh mempunyai riwayat keluarga dengan hipertensi, lebih dari separuh mempunyai riwayat merokok, lebih dari separuh tidak ada riwayat berolaharga.

Terdapat perubahan tekanan darah sistolik dan diastol yang bermakna antara sebelum dan setelah melakukan DMT pada kelompok perlakuan. Tidak terdapat perubahan tekanan darah sistolik dan diastol yang bermakna antara sebelum dan sesudah pada kelompok kontrol.

Ada perbedaan rerata tekanan darah sistol dan diastol responden pada kelompok perlakaun dan kelompok kontrol setelah dilakukan DMT.

\section{SARAN}

Bagi Puskesmas Kecematan Monta di harapkan mampu mengembangkan kebijakan untuk menerapkan DMT sebagai salah satu terapi komplementer untuk klien hipertensi dan menerapkan secara mandiri bagi masyarakat sebagai salah satu alternatif terapi disamping modifikasi gaya hidup yang masih harus tetap diterapkan.

Bagi institusi pendidikan keperawatandi harapkan Memasukkan DMT sebagai bahan kajian pendidikan keperawatan dan mengembangkan dalam berbagai kegiatan guna meningkatkan pemahaman pentingnya salah satu terapi komplementer pada pasien hipertensi.

Bagi penelitian selanjutnya perlu dikembangkan penelitian lebih lanjut tentang DMT dengan menghubungkan variabel perancu serta mengolah sampai data multivariat, Perlu dikembangkan penelitian lebih lanjut tentang DMT dengan lebih memperhatikan usia, riwayat HT keluarga, riwayat merokok dan olahraga, Perlu dikembangkan penelitian lebih lanjut tentang DMT yang dipadukan dan atau dibandingkan dengan terapi komplementer keperawatan yang berfokus exercise pada klien dengan hipertensi ataupun penelitian yang berfokus pada exercise dengan menggunakan alat selain DMT. 


\section{DAFTAR PUSTAKA}

Abdulsalam, S., Olugbenga, B. A., Olarewaju, O., Abdussalam, I. (2014). Sociodemographic Correlates of Modifiable Risk Factors for Hypertension in a Rural Local Government Area of Oyo State South West Nigeria. International journal of hypertension, 1-9. http://dx.doi.org/10.1155/2014/842028

Agarwal, B., Chowdhry, M., Mullerpatan, R. P., \& Kaul, S. K. (2014). Effect of Movement Therapy on Academic Stress in Physiotherapy Students. MGM Journal of Medicine Sciences. doi:10.5005/jp-journals-10036-1033

Amriana, F. (2012). Hubungan antara Stress dengan Kejadian Hipertensi pada Lansia di Shelter Dongkelsari Desa Wukirsari Kecamatan Cangkringan Kabupaten bupaten Sleman Provinsi DIY

Andri, J., Waluyo, A., Jumaiyah, W., \& Nastashia, D. (2018). Efektivitas Isometric Handgrip Exercise dan Slow Deep Breathing Exercise terhadap Perubahan Tekanan Darah pada Penderita Hipertensi. Jurnal Keperawatan Silampari, 2(1), 371-384. https://doi.org/https://doi.org/10.31539/jks.v2i1.382

Aweto, H. A., Owoeye, O. B., Akinbo, S. R., \& Onabajo, A. (2012). Effects of Dance Movement Therapy on Selected Cardiovascular Parameters and Estimated Maximum Oxygen Consumption in Hypertensive Patients. Nigerian Quarterly Journal of Hospital Medicine, 22(2), 125-9

Black, M. J., \& Hawks, H, J. (2009). Medical Surgical Nursing: Clinical Management for Continuity of Care, 8th ed. Philadephia: W.B. Saunders Company

Cahyani, H. (2014). Hubungan Shalat terhadap Tekanan Darah pada Pasien Hipertensi di Posyandu Anggrek Kelurahan Cempaka Putih Kecamatan Ciputat Timur. UIN Syarif Hidayatullah

Cheriyan, J., Eniery, C., \& Wilkinson, I. (2010). Hipertension. New York: Oxford University Press

Irawan, O. (2017). Pengaruh Terapi Rendam Air Hangat pada Kaki Sambil Mendengarkan Musik Klasik terhadap Penurunan Tekanan Darah pada Penderita Hipertensi di Wilayah Kerja Puskesmas Basuki Rahmad Kota Bengkulu. Poltekkes Kemenkes BKL

Lidya, H. A. (2009). Studi prevalensi dan determinan hipertensi di propinsi Kepulauan Bangka Belitung tahun 2007, 8

Mahmudi, A. (2012). Hubungan Stres dengan Kejadian Tingkat Hipertensi di Puskesmas Nusa Indah Kota Bengkulu Tahun 2012. Bengkulu: STIKES Dehasen Bengkulu

Makhfudli, E. F. (2013). Keperawatan Kesehtan Komunitas, Teori Praktik dalam Keperawatan. Jakarta: Salemba Medika

Padila, P. (2012). Buku Ajar Keperawatan Medikal Bedah. Yogyakarta: Nuha Medika

Potter, P.A, Perry, A.G. (2005). Buku Ajar Fundamental Keperawatan : Konsep, Proses, dan Praktik. Edisi 4.Volume 2. Alih Bahasa: Renata Komalasari, dkk. Jakarta: EGC

Pradono, J. (2010). Faktor-Faktor yang Mempengaruhi Terjadinya Hipertensi di Daerah Perkotaan (Analisis Data Riskesdas 2007). Pusat Teknologi Intervensi Kesehatan Masyarakat, Balitbangkes. Gizi Indon, 1(33), 59-66

Rahyani, R. (2007). Faktor yang Mempengaruhi Kejadian Hipertensi pada Pasien yang Berobat di Poliklinik Dewasa Puskesmas Bangking Periode Januari-Juni 2007. http://yayanakhyar.files.wordpress.com/2009/02/files-of-drsmedfaktor-yangberhubungan-dengan-kejadian-hipertensi.pdf

Riskesdas. (2007). Badan Penelitian dan Pengembangan Kesehatan Departemen Kesehatan, Republik Indonesia, Jakarta

Riskesdas. (2013). Riset Kesehatan Dasar (Riskesdas) 2013. Laporan Nasional 2013, 1-384. https://doi.org/1 
Rosano, G. M., Vitale, C., \& Fini, M. (2006). Hormone Replacement Therapy and Cardioprotection: What is Good and what is Bad for the Cardiovascular System? Annals of the New York Academy of Sciences, 1092, 341-8

Sacher, A. R., Mcpherson, A., \& Richard, R. (2004). Tinjauan Klinis Hasil Pemeriksaan Laboratorium. Jakarta: EGC

Sarif, L. O. (2012). Asuhan Keperawatan Gerontik Yogyakarta: Nuha Medika

Sartika, A., Wardi, A., \& Sofiani, Y. (2018). Perbedaan Efektivitas Progressive Muscle Relaxation (PMR) dengan Slow Deep Breathing Exercise (SDBE) terhadap Tekanan Darah Penderita Hipertensi. Jurnal Keperawatan Silampari, 2(1), 356-370. https://doi.org/https://doi.org/10.31539/jks.v2i1.380

Setyoadi, S., \& Kushariyadi, K. (2011). Terapi Modalitas Keperawatan pada Klien Psikogeriatrik. Jakarta: Salemba Medika

Sugiharto, A. (2007). Faktor-Faktor Risiko Hipertensi Grade II pada Masyarakat. Universitas Diponegoro Semarang

Sugiharto, A., Suharyo, H., Sukandarno, A., \& Shofa, C. (2003). Faktor-Faktor Risiko Hipertensi Grade II pada Masyarakat (Studi Kasus di Kabupaten Karanganyar). http://eprints.undip.ac.id

Susilo, T., \& Wulandari, A. (2011). Cara Jitu Mengatasi Hipertensi. Yogyakarta: Penerbit Andi

Weuve, J., Kang, J. H., Manson, J. E., Breteler, M. B., Ware, J. H., \& Grodstein, F. (2004). Physical Activity, Including Walking and Cognitive Function Inolder Women. JAMA, 292(12),1454-1461

Yuliarti, Y. (2007). Faktor-Faktor yang Berhubungan dengan Hipertensi pada Usia Lanjut di Posbindu Kota Bogor tahun 2007. Universitas Indonesia 